\title{
SOME OBSERVATIONS ON THE NATURE OF INCOME, GENERALLY ACCEPTED ACCOUNTING PRINCIPLES, AND FINANCIAL REPORTING*
}

\author{
Willard J. Graham $\dagger$
}

\section{INTRODUCTION}

The word income is used indiscriminately with several quite different meanings. Webster defines income as "that gain or recurrent benefit (usually measured in money) which proceeds from labor, business, or property," and also as "revenues" or "receipts." To the ordinary individual, income usually means receipt of money. Economists, however, are interested primarily in real income, which they think of as a flow of goods or services or as a flow of satisfactions of human wants.

In business and in popular speech income has been limited usually to monetary income, and to a large extent has replaced the word profit in the accountant's vocabulary, particularly with respect to business entities. Concepts of business income vary considerably. Statute law, common law, legal decisions, economics, and accounting have all contributed to the different concepts of business income. "The period of time, point of view, level of reference, and type of measurement, however, must be stated by the user for the concept of income to be clearly understood by others."2

The concept of business income and its measurement have received considerable attention in the last fifty years from both theorists and practitioners in various disciplines. Yet, in spite of all the time and effort that have been devoted to it, there still remains largely unresolved the question as to what constitutes the most practically useful concept of business income and how it should be measured for various purposes.

Part I of this article deals with the problems of income definition and measurement and with the usefulness of different concepts of business income in understanding and interpreting the reported income of individual business corporations.

In Part II, as an introduction to the succeeding articles in this symposium, an attempt is made to describe briefly the present status in the development of principles and procedures underlying financial reporting and to indicate the broad areas of

\footnotetext{
* Portions of this article have been adapted from a research report prepared under the dircction of the author by Erma L. Adams, Chairman, Department of Business Administration, Antioch College.

† A.B. 1921, LL.D. 1952, Tarkio College; A.M. 1924, Ph.D. 1934, University of Chicago; LL.D. 1965, George Washington University. Professor of Accounting and Director of the Exccutive Program, School of Business Administration, University of North Carolina. Certified Public Accountant, Illinois. Contributor of articles to accounting journals.

${ }^{1}$ Webster's New Collegiate Dictionary 421-22 (1960).

2 Thonas R. Prince, Extension of the Boundaries of Accounting Theory 62 (1963).
} 
disagreement among accountants concerning the nature and content of "generally accepted accounting principles."

The Nature of Income

\section{A. Various Concepts of Business Income}

\section{The Economic Concept of Business Income}

Economists have advanced many theories of business income, but no one theory has been accepted as the correct one. A few selected theories are given here in order to illustrate the development of the economic view of business income.

In 1776 , Adam Smith considered profits as a "rent" or return on stock (capital), as is shown from the following quotation:

An independent manufacturer, who has stock enough both to purchase materials, and to maintain himself till he can carry his work to market, should gain both the wages of a journeyman who works under a master, and the profit which that master makes by the sale of the journeyman's work. His whole gains, however, are commonly called profit, and wages are, in this case too, confounded with profit. ${ }^{3}$

Alfred Marshall, in I89o, expressed the following theory of business income:

When a man is engaged in business, his profits for the year are the excess of his receipts from his business during the year over his outlay for his business; the difference between the value of his stock and plant at the end and at the beginning of the year being taken as part of his receipts or as part of his outlay, according as there has been an increase or decrease in value. ${ }^{4}$

This definition of business income embraced the concept of maintaining capital intact. It makes no distinction between operating profit and so-called "capital gains."

Perhaps the most quoted definition of business income and the one that has gained the most acceptance among contemporary economists is an adaptation of J. R. Hicks' definition of an individual's income in which the income of a business for a particular year is regarded as being the amount that could be distributed in dividends while permitting the business to remain as "well off" at the end of the year as it was at the beginning. ${ }^{5}$ However, there has been much discussion as to what is meant by being as "well off"-whether this means the maintenance of financial capital, physical capital, or equivalent purchasing power. Implicit in such a definition is the premise that the problem of measuring income is inseparable from the problem of measuring changes in the value of equity or capital. This has been called the equity-change approach to the measurement of business income.

\footnotetext{
${ }^{3}$ Adam Smith, The Wealth of Nations 53 (Cannan ed. 1937) (footnotes omitted).

- Alfred Marshall, Principles of Economics 25 (ist ed. I890).

"See J. R. Hicks, Value and Capital 172 (1946).
} 
The limitations of economic income were pointed out by Sidney S. Alexander as follows:

The very nature of capital assets involves an evaluation of future receipts. Such an evaluation is complicated by three serious difficulties. First, and most important, the future receipts are not known, but can only be estimated. Secondly, a dollar in the future is not worth a dollar today even if the purchasing power should remain constant; this is reflected in the phenomenon of interest. Finally, the purchasing power of money does not remain constant. ${ }^{6}$

Although the practical applicability of the economist's theory of income has been seriously questioned, it has value as an "ideal" or "yardstick" by which to evaluate other theories of business income. It has served to re-emphasize certain shortcomings in the accountant's procedure for measuring income, especially the failure to recognize increases in the value of assets prior to "realization" and the effect of fluctuations in the value of money. Furthermore, it has been useful in the development of the concept of national income.

\section{The Legal Concept of Business Income}

As business has become more complex, accounting principles have frequently become involved in legal disputes. "Generally accepted accounting principles" have been both adopted and rejected by the courts, the legislatures, and regulatory agencies for the determination of income.

The classic legal definition of income is the Supreme Court's interpretation of the term income as used in the sixteenth amendment. This definition was formulated by Justice Pitney in Eisner v. Macomber in I920:

For the present purpose, we require only a clear definition of the term "income," as used in common speech, in order to determine its meaning in the Amendment .....

After examining dictionaries in common use . . . we find little to add to the succinct definition adopted in two cases arising under the Corporation Tax Act of Ig09 ... "Income may be defined as the gain derived from capital, from labor, or from both combined," provided it be understood to include profit gained through a sale or conversion of capital assets, to which it was applied in the Doyle Case....

.... Here we have the essential matter: not a gain accruing to capital, not a growth or increment of value in the investment; but a gain, a profit, something of exchangeable value proceeding from the property, severed from the capital how-

\footnotetext{
'Alexander, Income Measurement in a Dynamic Economy, in Frve MoNographs on Business Income I, 26 (1950).

${ }^{7}$ National income has been defined as the total amount of goods and services that a nation could consume during one period and still keep its productive capacity intact to create an equal amount in the next period. An important part of national income is the net income from all businesses. Most of the basic data on business income for national income purposes comes from accountants' reports. However, since accounting conventions do not follow economic theory, accounting statements are adjusted to bring them more in line with the economist's concept of income. For example, adjustments are made in inventories and in charges for depreciation and depletion to reflect changes in the value of money, since various business costs are based on "heterotemporal" prices. In summary, the national income concept of business income is the accountants' measurement adjusted to the economist's concept as far as practicable.
} 
ever invested or employed, and coming in, being "derived," that is, received or drawn by the recipient . . . for his separate use, benefit and disposal:-that is income derived from property.

The essential elements of income in this definition are, first, realization-to be income it must be severed from capital; second, gain-income is not a mere return of capital but must be a gain (something above costs); third, the gain must arise out of production (i.e., "be derived from labor or capital or both"); fourth, appreciation in capital assets that is realized; and, fifth, a monetary concept.

Since rg20 the courts have seemed to use Eisner v. Macomber as a starting point, but opinions in individual cases have gradually moved away from this decision, particularly in respect to the concept of realization. There have been cases in which the courts have ruled that income could arise without a separation of the gain from capital; also, the criteria for determining when realization has occurred have been broadened.

In their decisions the courts have been careful to point out that net incomes for various purposes are not necessarily the same and that for many purposes they may be different from net income in the commercial or accounting sense. Except for the broad definition in Eisner v. Macomber there is little agreement among the various decisions on this subject from both federal and state courts. The court tends in each instance to base its opinion on the specific problem. Therefore, the judicial pronouncements on income cannot be accepted out of context.

In those cases that arise under contract law, the court endeavors to ascertain the accounting intent of the contracting parties and will not write into the contract "generally accepted accounting principles." If the problem relates to dividends, the courts will construe the applicable state statute to determine whether minimum requirements have been met. And if the problem relates to regulated businesses, the courts will usually enforce the accounting regulations laid down by the appropriate commission unless it can be shown that these methods are arbitrary or whimsical.

In summary, then, there is no one legal concept of business income. The courts are concerned with the intent of the various statutes and not with what the measurement of income ought to be. Legal concepts of income are of limited use in measuring business income except in situations similar or identical to those from which specific legal concepts evolved.

\section{The Concept of Taxable Business Income}

Since I9r3, federal income tax laws have been enacted under the authority of the sixteenth amendment, which reads as follows:

The Congress shall have power to lay and collect taxes on incomes, from whatever source derived, without apportionment among the several States, and without regard to any census or enumeration.

\footnotetext{
${ }^{8}$ Eisner v. Macomber, 252 U.S. 189, 206-07 (1920).
} 
Because the amendment failed to include a definition of the term income, the defining of the term in its constitutional sense rests, in the final analysis, not with Congress but with the courts. ${ }^{9}$

The Revenue Act of 1918 and the regulations thereunder contained the first full recognition of accrual accounting for tax purposes, creating in the words of George O. May, "a new body of doctrine, "income tax accounting." "10 This "new body of doctrine" was embodied in two sections of the law which remain virtually unchanged today. ${ }^{11}$ These two sections read in part:

Section 2ז2(b): The net income shall be computed upon the basis of the taxpayer's annual accounting period, ... in accordance with the method of accounting regularly employed in keeping the books of such taxpayer; but if no such method of accounting has been so employed, or if the method employed does not clearly reflect the income, the computation shall be made upon such basis and in such manner as in the opinion of the Commissioner does clearly reflect the income. ... ${ }^{12}$

Section 213: . . . The amount of all such items shall be included in the gross income for the taxable year in which received by the taxpayer, unless, under methods of accounting permitted under subdivision (b) of section 212, any such amounts are to be properly accounted for as of a different period $\ldots$. $^{13}$

There were two significant regulations under this act bearing on the accounting methods to be employed:

I. The time as of which any item of gross income or any deduction is to be accounted for must be determined in the light of the fundamental rule that the computation shall be made in such a manner as clearly reflects the taxpayer's income. ${ }^{14}$

2. Approved standard methods of accounting will ordinarily be regarded as clearly reflecting income $\ldots .^{15}$

Although the intent of Congress in 1918 , as shown by the foregoing quotations from the Revenue Act of that year, was that the taxable concept of business income and its measurement should be similar to the accounting concept, many differences between the two have developed. ${ }^{16}$

\footnotetext{
${ }^{\circ}$ See generally Lent, Accounting Principles and Taxable Income, 37 Accounting Rev. 479, 480 (I962).

${ }^{10}$ George O. May, Foreword to DaN T. Smith \& J. KeIth Butters, TAXadle Business Income at xviii (x949).

11 INT. REv. CODE OF I954, $\$ \$ 446,45$ I.

12 Revenue Act of 1918, ch. 18, $\$ 212(\mathrm{~b}), 40$ Stat. 1064 .

${ }^{13}$ Revenue Act of 1918 , ch. $18, \S 213,40$ Stat. 1065 .

14 Treas. Reg. 45, art. 22 (I919).

15 Treas. Reg. 45 , art. 23 (1919).

${ }^{10}$ The following is an illustrative classification of differences between business income and taxable income:

A. Income Taxed but Deferred in the Accounts-Amounts that are included in determining the taxable income of the current accounting period but that will be recognized and reported as busincss income in one or more future accounting periods.

Examples: Prepaid income that is taxable in the period of receipt but that is "spread" over earning periods, such as prepaid rent and unearned finance charges.

B. Costs Deferred Only for Tax Purposes-Amounts that are recognized and reported as expenses in
} 
Permanent differences include items of revenue and expense that are included by the accountant in determining net income but that are legally excluded for tax purposes. Examples are tax-exempt interest, nondeductible contributions to political campaigns, and other expenses nondeductible on the basis of equity or public policy. Permanent differences include also special tax deductions, such as depletion allowances, which are not usually considered to be proper business expenses.

Other differences between business income and taxable income are purely a matter of "timing"-allocation to specific periods. For example, income on installment sales is not taxable until it is collected, but it is ordinarily taken into business income at the time of the sale. Then too, in the construction industry and certain others, income may be reported for tax purposes at the time the contract is completed; for financial reporting the percentage-of-completion method is ordinarily preferable.

In recent years the income tax law has been used frequently to stimulate selected types of business activity. During the second World War and subsequently, to induce the construction of "emergency facilities" needed for military purposes, the tax law permitted the amortization of such facilities over a five-year period in the determination of taxable income. For financial reporting, these facilities were ordinarily depreciated over a longer period. Since I954, in order to stimulate the economy by the encouragement of capital investment, the tax law has provided that

the current accounting period but that will be taken as deductions in determining the taxable income of one or more future accounting periods.

Examples: (I) Accrual of estimated expenses for book purposes only; (2) larger depreciation charges on books than for tax purposes; and (3) estimated renegotiation refunds.

C. Costs Deferred Only in the Accounts-Amounts that are taken as deductions in determining the taxable income of the current accounting period but that will be recognized and reported as expenses in one or more future accounting periods.

Examples: (1) Accelerated amortization of emergency facilities for tax purposes only; (2) de-

clining-amount depreciation for tax purposes only; (3) unamortized discount on refunded bonds deducted currently for income-tax purposes but, in the accounts, amortized over the life of the refunded bond issue; and (4) cost of pension plans deducted earlier for taxes than in the accounts.

D. Income Deferred Only for Tax Purposes-Amounts that are recognized and reported as business income in the current accounting period but that will be included in determining the taxable income of one or more future accounting periods.

Examples: (I) Instalment sales method used only for tax purposes; and (2) percentage-of-

completion method in the accounts but completed-contract method for tax purposes.

E. Losses Not Currently Deductible for Income-Tax Purposes-Decreases in the book value of (net) assets, accompanied by reductions in retained earnings or other capital accounts, that are not deductible in determining the taxable income of the current period (the period in which they occur) but that will enter into the determination of the taxable income of one or more future accounting periods.

Examples: (1) Write-down of investment securities to market values; and (2) appraisals downward.

F. Nontaxable Increases in the Book Value of (Net) Assets-Increases in the book value of (net) assets, accompanied by additions to retained earnings or other capital account, that do not constitute taxable income in the current period (the period in which they occur) and that suill not be deductible in determining the taxable income of future periods.

Examples: ( $I$ ) Appraisals upward; (2) involuntary conversions; and (3) nontaxable exchanges.

G. The Investment Credit-A special case. A statutory credit directly to income tax currently payable, computed as a percentage of capital investments made during the current period; the preferred treatment in computing business income is a current deferred credit to be written off over life of capital assets, perhaps to depreciation expense. 
accelerated methods may be used for the depreciation of new post-r953 capital investments in the determination of taxable income; in many cases the straightline method is considered more appropriate for financial reporting. Additional incentives to capital investment have been provided by permitting for tax purposes the deduction of initial depreciation allowances and allowing a credit directly to taxes computed as a percentage of additional capital investment; both of these items are normally handled differently for financial reporting than for the determination of taxable income.

\section{The Accounting Concept of Business Income}

If we were to choose a point in history when modern accounting can be said to have had its beginning, perhaps no specific time is more appropriate than the first half of the nineteenth century. This does not mean that noteworthy developments in theory had not occurred previously, but from this time forward accelerated economic changes caused the emergence of modern accounting.

With the advent of joint-stock companies and corporations and their separation of ownership and management, stockholders had no direct knowledge of business operations through personal contact; it followed that financial information was required more frequently. Furthermore, since corporations had perpetual lives, there was the necessity for maintaining capital intact, and careful distinction was required between capital and income. Later, when corporations were granted limited liability, this distinction between capital and income received even more emphasis in order to protect the equities of creditors. Therefore, the measurement of income, which involves the allocation of revenue and expenses to proper financial periods, became the raison d'etre of accounting.

During most of the nineteenth century, the balance sheet was the most important statement that a business unit used. Emphasis was placed on the security of loans, and the creditors were much interested in the realizable value of assets.

For many years the "net worth" method was used for determining income. It was assumed that a proper valuation of assets and liabilities would result in a correctly valued owners' equity. The difference between owners' equity from one balance sheet date to another was considered income-in the absence of additional investment or withdrawals. The income statement was considered little more than a supporting schedule, and scant attention was given the problems of income determination or presentation.

As business units increased in size and complexity during the twentieth century, the problems of correct income determination became more important and the emphasis shifted from the balance sheet to the income statement. This shift in emphasis was further accelerated by the passage of income tax laws, legislation for the regulation of utilities and new security issues, and other regulations that required disclosure of financial information. 
It is now generally agreed that one of the most important functions of accounting is the measurement of income. Strangely enough the accounting profession has been criticized for its failure to define the term income in a clear, unequivocal manner so that it will convey a definite meaning to the user of financial reports. The profession has been further criticized (I) for its failure to set up a codification of concepts, principles, and standards for the measurement of income that must be accepted and applied uniformly to all enterprises in a given industry; (2) for allowing the federal income tax statutes to have undue influence in the measurement of income for purposes other than taxes; and (3) for its failure to recognize, in the measurement of income, fluctuations in the value of the dollar. ${ }^{17}$

Much of this criticism has validity, but part is due to the misunderstanding about the basic concepts, principles, conventions, and procedures of accounting. Professor Walter $F$. Frese expressed it as follows:

Generally, the character of accounting is not fully understood either by the people who use it as a means of communicating the results of operations for which they are responsible (business managers) or by the people to whom such results are communicated (stockholders, investors, labor, general management and others). Those at both ends of this communication process often believe that somewhere in the middle the accountant, through application of mysterious specialized techniques, can translate the facts and judgments underlying business transactions into quantitative terms, predigest them, and come out at the end of the process with figures which precisely measure the results of business operations. ${ }^{18}$

More recently accounting principles and practices have received a great deal of attention in the business and financial press. Most of these articles have expressed, or implied, that financial statements as now prepared do not satisfy the needs of investors and others. It appears that too many accountants have considered themselves pragmatists (in the narrow sense of the word) and have not bothered to develop a philosophy of business income; they have been more concerned with the methodology of measurement than with the implications of their measurements.

The Committee on Accounting Procedure of the American Institute of Certified Public Accountants (AICPA) has issued the following pronouncement with regard to income:

[T] he word income is used to describe a general concept, not a specific and precise thing, and ... the income statement is based on the concept of the going concern. It is at best an interim report. Profits are not fundamentally the result of operations during any short period of time. Allocations to fiscal periods of both charges and credits affecting the determination of net income are, in part, estimated and

${ }^{17}$ See Kelley, Can Corporate Incomes Be Scientifically Ascertained?, 26 Accountring Rev. 289, 29I-93 (195I).

${ }_{18}$ Walter F. Frese, Foreword to Leonaro E. Morrissey, Contemporary Accounting Problems at v (1963). 
conventional and based on assumptions as to future events which may be invalidated by experience. ${ }^{10}$

There has been and still is disagreement among accountants not only on the question of what items shall be recognized as revenues and expenses but, more importantly, on when-in what period-they shall be reflected in the measurement of business income. Examples of conflicting practices which produce materially different periodic net incomes can be found in the following areas: alternative methods of costing goods sold and valuing inventories; the timing of income recognition on installment sales; widely different methods of accounting for depreciation and depletion and for research and development costs; failure to distinguish clearly between revenue and capital expenditures; and the disagreement-almost confusion-in accounting for pension costs.

In summary, there is little or no general agreement among accountants on a precise definition of business income, or its measurement. However, if allowances are made for differences in business customs, personal judgments, and the influence of conservatism, it may be said that accountants consider the net income of a business to be the excess of revenues realized over the historical costs incurred in and applicable to the generation of those revenues.

\section{B. The Matching Concept and the Problem of Timing}

Always implicit, but rarely explicit, in discussions of the measurement of income is a recognition of the basic fact that the determination of income is purely a matter of timing - the allocation of expense and revenue to the proper accounting period. This is basic to each of the various concepts of income. Under each concept, choice among alternative accounting principles may have a substantial effect upon the net income of successive accounting periods, but the total net income of all accounting periods will be precisely the same regardless of what accounting principles or procedures are followed.

Let us look at some examples. Total bad debt expense over a long period of time will be the same under the "reserve method" as under the "write-off method." The choice between different methods of inventory valuation and costing goods sold does not have a permanent effect upon total net income over time. Total expenditures on fixed assets at acquisition and subsequent to acquisition, less net salvage at retirement, will be charged against the operation of all of the years of service life; this total charge will not be affected by capital-versus-revenue decisions at acquisition, by the estimate of service life, by the choice of depreciation method, by the distinction between repairs and replacements or by any other accounting decision. The total net income from installment sales over a long period of time will not be influenced by the choice between the sales method and collection method of recognizing

\footnotetext{
${ }^{19}$ Committee on Accounting Procedure, AicPa, Restatement and Revision op Accounting ReseArCh Bulletins 59 (Accounting Research Bull. No. 43, I953).
} 
revenue. Decisions to defer or not to defer expense or income will have no permanent effect on total net income.

The problem is not what is revenue or what is expense but rather when should revenue be recognized and when must a cost be charged as an expense in order to be "matched" appropriately with the revenue resulting from (or responsible for) the expense. This is not to say that the measurement and reporting of periodic income is not important just because it is purely a matter of timing. It is most important that revenue and expense be allocated to the proper accounting period and that revenue and expense be properly matched. Only upon the basis of reasonably accurate periodic net income figures of past periods can the probable future trend of income be estimated and the earning power of the business be determined. Only within a body of "sound" accounting principles, together with rules for the application of these principles to specific situations, will it be possible for management and the accountant to exercise the quality of judgment that will result in periodic financial statements that are most useful to their readers.

\section{The Balance Sheet as a Residual Statement Dependent on Income Measurement}

Most of the significant controversial issues in financial reporting relate primarily to the measurement of income-the allocation of revenue and expense to the proper accounting periods and their reporting on the income statement for the period. This is not to say that the balance sheet-the statement of financial position-is not an important financial report. It is only to say that most of the amounts on the balance sheet are residual figures, that they are the resultants of decisions which have been made from the point of view of the income statement. To demonstrate the extent to which the balance sheet is a "residual" statement there is presented below an itemby-item analysis of the dependence of balance-sheet amounts upon decisions relating to the timing of revenue and expense. This analysis should justify the emphasis here upon the measurement of income and the amounts on the income statement rather than upon the amounts appearing on the balance sheet.

The net value of receivables is the result of decisions with respect to the periodic charge to bad debt expense. Accrued income or an accrued receivable, such as interest receivable, reflects management's decision to recognize revenue in advance of its receipt. Inventory values ordinarily reflect decisions to charge against cost of goods sold either current costs, past costs, or average costs, and perhaps a decision to charge to loss or expense an amount by which the market value of the inventory is lower than its cost. Marketable securities appear at an amount lower than cost only if the decision has been made to charge against expense a decline in their market value.

The presence of prepaid expenses reflects past decisions to defer the charge for certain expenditures to future periods rather than to charge them against the period 
of expenditure. For example, "Research and Development" on the balance sheet indicates that, in the judgment of management, these expenditures are more appropriately chargeable against future periods than to the current period, the period of expenditure.

To a certain extent the amounts appearing as costs of fixed assets reflect a choice between capital and revenue charges at the time the assets were acquired. The balance of accumulated depreciation reflects several kinds of decisions, all made from the point of view of income measurement. There have been added to this account the amounts that in past periods were considered to be appropriate charges to depreciation expense. There have been deducted from this account the cost of assets retired, less salvage and less amounts that in the opinion of management were appropriately shown as losses or gains on retirement. The amounts of the fixed asset accounts and the accumulated depreciation are both affected by management's decisions governing the distinction between (I) repairs and maintenance to be charged as expenses of the current period, and (2) replacements, renewals, additions, and improvements to be charged either to the fixed asset account or to accumulated depreciation. This distinction depends upon the size of "property retirement units,"20 whether they be stated in physical terms or in monetary terms. But the size of the property retirement unit is in fact governed by the amount of the annual depreciation charge to be added to accumulated depreciation. The larger the annual depreciation charge the larger will be the total amount of capital expenditures that may be charged against this account; hence, the smaller the proper size of the property retirement unit. Conceivably, if the annual depreciation charge were large enough, all expenditures on fixed assets subsequent to their acquisition could be charged against accumulated depreciation. At the other extreme the depreciation charge could be so small that all subsequent expenditures would have to be charged to repair and maintenance in the period of expenditure. It is evident, therefore, that management's decision about the amount of the annual depreciation charge, determined from the standpoint of income, actually determines the size of the property retirement unit, the distinction between capital and revenue charges resulting from expenditures on fixed assets subsequent to their acquisition, and hence the balance sheet amounts of both fixed assets and accumulated depreciation. It is obvious that management decisions in this area would be based upon what appears to be a proper allocation of all fixed asset costs among the periods of their use rather than upon the determination of proper balance sheet amounts.

\footnotetext{
${ }^{20} \mathrm{~A}$ "property retirement unit" is an amount of physical property (such as 50 fect of 20-pair cable, a complete telephone instrument, Ioo feet of continuous track, 200 feet of continuous pole line, and so on). When an amount of property less than a property retirement unit is replaced, the cost of replacement is charged to repair and maintenance expense, while the cost of replacement equal to or greater than a "unit" is "capitalized." Where a classification on a physical basis is not feasible, the definition may be in monetary terms (such as $\$ 100$ for office machines, $\$ 400$ for trucks, $\$ 1500$ for certain automatic screw machines, and so on). Expenditures less than these amounts are charged to expense, while larger amounts are capitalized.
} 
Appropriate titles for fixed asset and depreciation accounts, which would reflect more accurately their true nature, might be as follows: on the balance sheet, "Cost of Plant"; on the income statement, in lieu of "Depreciation Expense," "That Part of Plant Cost Which Has Been Charged Against the Operations of the Current Period"; on the balance sheet, in lieu of "Accumulated Depreciation," "That Part of Plant Cost Which Has Been Charged Against the Operations of All Periods to Date"; on the balance sheet, in lieu of "Plant Cost Less Accumulated Depreciation," "That Part of Plant Cost Which Remains to be Charged Against the Operations of Future Periods."

On the right side of the balance sheet many of the current liabilities, such as interest payable, taxes payable, wages payable, and so on, reflect the decision of management to charge these items to expense in advance of their actual payment. Many so-called "liability reserves," such as "provision for guaranty expense," reflect the decision of management to charge against the period of sale an estimate of expenditures that will take place in the future. Deferred income taxes, which would be more appropriately titled "deferred credits to income tax expense," reflect two management decisions made from the point of view of the income statement: (I) a decision to defer for financial reporting an expense item that is deducted currently in the determination of taxable income, or to recognize in the current period, for financial reporting, a revenue item that is deferred in the determination of taxable income, and (2) a decision to charge to income tax expense of the current period an amount based on reported income rather than an amount based on the income that is taxable in the current period.

Indeed, it would seem that almost all balance sheet amounts are "residual" except most accounts payable, notes payable, bonds payable, and the accounts reflecting paidin capital; the amounts of these items only are independent, or virtually so, of decisions made primarily from the point of view of income measurement.

In special circumstances there may be other exceptions to the dependence of balance sheet amounts upon income decisions. For example, a management decision to capitalize long-term leases may be made primarily from the point of view of balance sheet presentation; even here, however, there are important income considerations. Also, decisions to recognize on the balance sheet, prior to their "realization," increases or decreases of asset values, with offsetting entries directly to capital accounts, may be made primarily from the point of view of balance sheet presentation. But these decisions may have important impacts upon the income of future periods, as, for example, an increase or decrease of future depreciation charges. This impact on future income may well be one of the major considerations in management's decision to restate these asset values.

The foregoing discussion may be summarized as follows: About the only balance sheet amounts that are not primarily the resultants of decisions made from the point of view of income measurement fall into two classifications: (I) amounts arising 
from transactions involving simultaneous recognition of equal increases (or decreases) of assets and liabilities and (2) transactions between the corporation and its stockholders. Even in these situations there may be some impact upon income arising from revenue or expense considerations. Most accounting principles (or postulates or conventions or concepts), when thoughtfully analyzed, are seen to reflect more concern for proper allocation of revenue and expense among accounting periods than for "correct" balance sheet amounts.

A balance sheet may best be understood as a dual analysis of the total capital (assets) of the business-a statement of sources of the total capital (assets) and the present net investment of that total in specific asset items. Perhaps the primary determinant of the amount of the current net investment in most asset items is in the "timing"-the expiration (consumption, depreciation, amortization) of asset items, which depends, of course, upon management decisions made from the point of view of income determination.

\section{Price Level Changes and the Income Statement}

If this section seems to be a digression from the main theme of the discussion, it is not so intended. This subject is highly pertinent at this point because the failure to reflect in financial reports the impact of the changing value of the dollar upon financial conditions and particularly upon net income has been perhaps the greatest obstacle to the achievement of the primary objective of financial statements-usefulness as a basis for appraising management and particularly in estimating futture earning power and financial strength.

The accountant's concept of income, which is presently the basis for "generally accepted accounting principles," was defined earlier as the excess of revenues realized over the historical "costs" incurred and applicable to generating those revenues. This definition of net income reflects the results of operations measured in dollars of various sizes and completely ignores changes in the general price level. Such a concept is useful only in satisfying legal, contractual, and regulatory provisions where "original costs" are specified or required. At present, this definition of income provides the most practical basis for taxation (except for the specific differences already mentioned) and for rate-making for regulated companies and as the basis for innumerable contractual and business relationships. However, this is true only because a "vast body of common and statutory law and legal precedent, innumerable contractual and business relationships, and many regulatory provisions are presently founded on existing accounting practices."21 A much more useful measurement of business net income for these and most other purposes could be provided by accountants if the "stable monetary unit" assumption were abandoned. Then net income

\footnotetext{
21 Committee on Concepts and Standards, American Accounting Ass'n, Price Level Changes AND Financial Statements (Supplementary Statement No. 2, 1951), reprinted in 92 J. Accountancr $46 I, 462$ (I95I).
} 
would be measured as the excess of revenue over costs, both expressed in dollars of the same size.

During the long period of increasing prices beginning in 1938 there has been a great deal of criticism of the accounting profession for its failure to recognize changes in the value of the dollar in the measurement of business income. This criticism has come from both accountants and nonaccountants. Many studies have shown that profits (net income) for businesses during this period have been materially overstated in terms of purchasing power and that real capital has not been kept intact. These same studies indicate that financial condition has been substantially understated in terms of current dollars. ${ }^{22}$ As a result of this criticism and the widespread concern of businessmen and members of the accounting profession, the Accounting Principles Board of the AICPA, in I96r, took the action summarized in the following excerpt from its minutes:

$[T]$ he Board ... agreed that the assumption in accounting that fluctuations in the value of the dollar may be ignored is unrealistic, and that therefore the Director of Accounting Research should be instructed to set up a research project to study the problem and to prepare a report in which recommendations are made for the disclosure of the effect of price-level changes upon the financial statements. In this study, special attention should be paid to the use of supplementary statements as a means of disclosure. ${ }^{23}$

The report of this research project was published in October, $1963,{ }^{24}$ but no action on it has been taken by the Board. The main recommendation was that the effects of price-level changes should be disclosed as a supplement to conventional statements; this disclosure could take the form of physically separate statements, or of parallel columns in a combined statement, or of detailed supporting schedules (including charts and graphs) or some combination of these. In the supplement all items should be adjusted by using an index of the general price level as of the balance sheet date so that the data would be expressed in dollars of the same size. The following were listed as minimum requirements for adequate disclosure:

I. Sales or other major source of revenue. Unadjusted and adjusted amounts should be compared for a period of years, either in current dollars or as percentages of a base year.

2. Net profit. The unadjusted (conventional) amount, and the amount of net profit that results from the adjustment of the component items (revenues and expenses) for price-level changes, should be compared for a period of years.

3. Common stockholders' equity. Sufficient information should be presented to permit the calculation of the adjusted rate of return over the period of years for which net profit figures are shown.

4. Purchasing-power gains and losses on monetary items. The amount of these

${ }^{23}$ E.g., Staff of Accounting Research Div., AICPA, Reporting the Financtal Effects of PriceLevel Changes 169-249 (Accounting Research Study No. 6, 1963).

${ }^{33}$ Quoted in id. at 1 .

${ }^{34}$ Staff of Accounting Research Drv., op. cit. sispra note 22. 
gains and losses should be shown, together with an indication as to how they have been treated in the calculation of net profit and the common stockholders' equity. ${ }^{25}$

The foregoing recommendations are similar to those of the Study Group on Business Income in $1952 .{ }^{2 B}$ At that time, however, there was much opposition to the proposal, and the Committee on Accounting Procedure of the Institute rejected it by issuing Accounting Research Bulletin No. 43, in which it reaffirmed the "stable monetary unit" principle. ${ }^{27}$

It is hoped that the recommendations in the $\mathrm{I}_{96} 6_{3}$ Study will not be ignored, since business income so measured would be much more useful for many purposes, including the following: (I) accounting for "stewardship"-where "accountability" implies responsibility for preserving the purchasing power of invested capital and not just its initial dollar amount; (2) appraising managerial efficiency; (3) estimating profitability, current and future; (4) granting credit; (5) planning expansion; (6) investment information; (7) evaluating pricing policy; (8) determining wage policy; (9) creation of an informed public opinion with respect to profits, prices, and wages; (Io) explaining dividend policy to stockholders; (II) negotiating with labor unions; and (I2) as a basis for sound government economic policies.

The area of difference between the accountants' concept of business income and the economists' concept would be narrowed if price-level adjustments were made, but it would not be completely eliminated. It was stated earlier that a concept widely employed by economists is that business income should be measured by future expectations, and the problems of measurement under such a concept were described. However, if the accountants would revise their concept of income to include provision for reflecting the effect of price-level changes, the economists would be provided with more useful data for their purposes.

\section{II}

\section{Generally Accepted Accounting Prunctples}

\section{A. Postulates-Principles-Procedures}

It is quite evident that there are broad areas of disagreement among accountants as to the nature, content, meaning, and proper application of accounting principles. There is even greater disagreement, amounting almost to confusion, about the terminology to be used to describe these so-called principles. In the literature are found terms such as postulates, principles, concepts, conventions, standards, practices, and procedures. These terms are used almost indiscriminately.

The Special Committee on the Research Program of the AICPA, in its 1958 report, offered this terminological sequence:

\footnotetext{
${ }^{25} 7 d$. at 55 .

${ }^{20}$ Study Group on Business Income, Changing Concepts of Business Income (1952).

${ }^{97}$ Comantiee on Accounting Procedure, op. cit. stipra note 19, at 67-71.
} 
(I) Postulates were regarded as being "few in number" and were expected "to provide a meaningful foundation for the formulation of principles."

(2) Principles were to be "formulated on the basis of the postulates" and were "to serve as a framework of reference for the solution of detailed problems."

(3) "Rules or other guides for the application of principles in specific situations" were to be "developed in relation to the postulates and principles" and were to have "reasonable Alexibility."28

Aside from the current confusion with respect to terminology, there is probably substantial agreement among accountants that there should be three broad categories or "levels" of so-called "accounting principles," which might well be called respectively "postulates," "principles," and "rules" or "procedures." There is undoubtedly substantial disagreement as to what these "principles" should be and in which of the three categories a particular concept fits most appropriately.

\section{B. Some Efforts at Stating the Fundamentals}

In his recent Inventory of Generally Accepted Accounting Principles for Business Enterprises, a research study prepared under the direction of the Accounting Principles Board, Paul Grady listed ten "basic concepts." He states,

[I]t is believed that each of the ten concepts listed below may be justified as providing qualities of usefulness and dependability to accounting information or as setting forth limitations inherent in financial statements produced by the accounting process:

I. A society and government structure honoring private property rights

2. Specific business entities

3. Going concern

4. Monetary expression in accounts

5. Consistency between periods for the same entity

6. Diversity in accounting among independent entities

7. Conservatism

8. Dependability of data through internal control

9. Materiality

Io. Timeliness in financial reporting requires estimates. ${ }^{29}$

In an earlier Accounting Research Study (No. I), ${ }^{30}$ Maurice Moonitz proposed fourteen "postulates," which are set forth in Appendix A at the end of this symposium. It will be noted that seven of Moonitz's fourteen "postulates" essentially correspond to seven of Grady's ten "basic concepts."

\footnotetext{
${ }^{28}$ Spectal Comm. on Research Program, Aicpa, Report to Council (1958), reprinted in J. Accountancy, Dec. 1958, at 63 .

30 Paul Grady, Inventory of Generaliy Accepted Accounting Principles for Business EnterPRISES 24 (AICPA Accounting Research Study No. 7, 1965).

${ }^{80}$ Maurice Moonitz, The Basic Postulates of Accounting (AICPA Accounting Research Study No. I, I96I).
} 
In another Accounting Research Study (No. 3), ${ }^{31}$ Moonitz and Robert T. Sprouse have discussed eight major principles and several "sub-principles," which are presented in Appendix B at the end of this symposium. In addition, Paul Grady has included in his Inventory a statement of thirty-two accounting "principles" (or "practices"). These are set forth in summary fashion in Appendix C. A review of these two statements of "accounting principles" reveals major differences in stated or implied objectives, concepts, nature, and content, as well as in classification. Significant in the statement of Sprouse and Moonitz are departures from the "cost" principle and the "realization" principle. It is only fair to state that much of the difference between the two statements may be due to the fact that Grady describes existing practice while Sprouse and Moonitz are attempting to break new ground.

Another prominent effort at stating fundamentals should be mentioned. In a booklet prepared by Arthur Andersen \& $\mathrm{Co}$., it is contended that there is only one basic accounting postulate, which is stated as follows:

Thus, the one basic accounting postulate underlying accounting principles may be stated as that of fairness-fairness to all segments of the business community (management, labor, stockholders, creditors, customers and the public), determined and measured in the light of the economic and political environment and the modes of thought and customs of all such segments-to the end that the accounting principles based upon this postulate shall produce financial accounting for the lawfully established economic rights and interests that is fair to all segments. ${ }^{32}$

Finally, an unpublished manuscript on accounting theory attempts to avoid the terminology problem by the following classification of accounting "conventions":

A. Four basic agreements about accounting which are not questioned:

r. The utilitarian nature of accounting

2. The entity convention

3. The accounting-period convention

4. The going-concern convention

B. Four conventions inherently limiting the significance of accounting statements: (All are directly related to the impossibility of consistently showing value changes in the records. All are based on the need for objectivity.)

r. The use of historical cost

2. The standard-money convention

3. The realization convention

4. The convention of matching costs with revenues

C. Four conventions primarily related to accounting practice, emphasizing the statements and reflecting the attitudes of auditors:

x. Full-disclosure

2. Materiality

\footnotetext{
${ }^{a 1}$ Robert T. Sprouse \& Maurice Moonitz, A Tentative Set of Broad Accountino Principles fon Business ENTERPrises (AICPA Accounting Research Study No. 3, 1962).

29 Arthur Andersen \& Co., The Postulate of Accounting 3i (1960).
} 
3. Consistency

4. Conservatism

D. Miscellaneous: The convention as to contributed and earned income. ${ }^{\mathbf{3 3}}$

C. Alternative Generally Accepted Accounting Principles

In his Inventory, Paul Grady lists thirty sets of "alternative methods of implementing generally accepted accounting principles." ${ }^{34}$ Appendix D at the end of this symposium sets forth this list in its entirety. The list is comprehensive and includes all the important so-called "alternative generally accepted accounting principles."

The thirty sets of alternatives in Grady's list may be classified into three categories: (I) alternatives available in situations where there are no significant differences in circumstances, (2) alternatives available in situations where there are significant differences in circumstances that in current practice are ordinarily ignored in selecting the alternative to be employed, and (3) alternatives available in situations where there are significant differences in circumstances that are now quite generally considered in selecting among the alternatives. The first and second categories are the only ones causing concern in the on-going debate over uniformity in financial accounting. Without pursuing the arguments that might be raised either way, I would suggest that the particular items in these two categories are as follows (listed in the order in which they appear in Grady's Inventory and Appendix D):

Category I: Situations in which alternatives are available even though there are no significant differences in circumstances

Recognition of revenue on long-term contracts

Accounting for cash (sales) discounts

Inclusion (or exclusion) of excise taxes in sales and cost of sales

Pension expense and liability (Legal and contractual differences that do exist bear little or no relation to the choice among a multitude of alternative practices.)

Timing of the charge for real and personal property taxes

Inter-period income tax allocation

Accounting for the investment income tax credit

Treatment of extraordinary gains and losses

Pricing of property other than cash distributed to stockholders as a dividend

Investments in unconsolidated subsidiaries

Unamortized discount and expense on bonds refunded

Accounting for cash (purchase) discount

${ }^{33}$ Vern H. Vincent, Interpretative Accounting Theory (unpublished).

as GRADY, op. cit. stupra note 29, at 51-52. 
Repair and renewal costs

Fire losses, when no fire insurance is carried

Category 2: Situations in which alternatives are available where there are significant differences in circumstances but in which circumstances are ordinarily ignored in selecting the alternative to be employed (At the very least, these significant differences do not control the choice of alternatives.)

Choice of depreciation method

Choice of base for depletion charges

Choice of method for costing goods sold and inventory valuation (Income tax considerations control choice between LIFO and FIFO.)

Amortization of "unlimited life" intangibles

Costs of research, development, and experimentation

Recording the value of properties constructed

Distinction between "capital" and "revenue" charges with respect to expenditures on property subsequent to its acquisition (except most public utility companies and a relatively few industrial companies)

Property conversion and abandonment losses (except for a sharp distinction between regulated and nonregulated companies)

Capitalization of the cost of containers

Classification of spare parts for machinery

Cost of patterns, jigs, and small tools

Development costs of extractive industries

Material leases of property in the accounts of the lessee

There is substantial disagreement among accountants about the desirability of the wide diversity in the application of accounting principles reflected in the listed alternatives. At one extreme there are accountants who favor wide diversity and who believe that there is no necessity for major changes in current practice. At the other extreme there are accountants who believe in a high degree of uniformity. These latter accountants would permit alternatives only in those situations where there are significant differences in circumstances; furthermore, they would insist that these differences must always be considered in the selection and application of the appropriate alternative principle. They believe that there should be no free-choice alternatives -that the alternatives in category ( $I$ ) above should be eliminated and that only one principle should be available in situations where there are no significant differences in circumstances. Furthermore, they believe that the alternatives in category (2), where under current practice significant circumstantial differences are ordinarily ignored in the selection of a principle, should be retained but that accountants should be required to give consideration to the differences in circumstances in selecting among alternative principles. Between these two extremes there is a wide range of opinion with 
respect to the degree of diversity or the degree of uniformity that is most desirable in the selection and application of generally accepted accounting principles.

Aside from the absence of useful and accepted postulates, perhaps the most significant vacuum in the literature relating to generally accepted accounting principles is the almost total lack of criteria for the selection of specific procedures to implement the application of an accepted principle to a given situation. In an article soon to be published there appears an excellent analysis of this problem:

A current "bottleneck" in the development of accounting "principles" is that there are either no criteria or they have been so vaguely stated that they do not constitute an effective guide.

The Statement of the Committee on Accounting Procedure regarding depreciation is an example of the lack of an effective guide for selecting the most appropriate depreciation method:

"Generally accepted accounting principles require that this cost [of a productive facility] be spread over the expected useful life of the facility in such a way as to allocate it as equitably as possible to the periods during which services are obtained from the use of the facility. This procedure is known as depreciation accounting, a system of accounting which aims to distribute the cost or other basic value of tangible capital assets, less salvage (if any), over the estimated useful life of the unit (which may be a group of assets) in a systematic and rational manner. It is a process of allocation, not of valuation."29

This statement provides no meaningful basis for determining which depreciation method is the most systematic and rational in the circumstances. Grady's "principles" [see Appendix C at the end of this symposium] are not any more helpful. For example, again with respect to depreciation, he recommends the following "principles":

"A-3. Appropriate charges should be made for depreciation and depletion of fixed assets and for amortization of other deferred costs.

"C-3. Appropriate provision or allowance should be made in order to charge operations with the investment in depreciable assets over the estimated life thereof."

If the foregoing principles are meant to be criteria within the context of this discussion, then they are clearly not a meaningful guide to action.

In all fairness to Grady, however, it should be noted that he is trying to reflect the current status of accounting principles. Within this context he cannot very well present criteria which have never been formulated. The fault lies rather with the accounting profession for failure to do research to develop significant criteria or for failure to take advantage of the results of research already available. Enough has been done by Terborgh [George Terborgh, Director of Research, Machinery and Allied Products Institute] and others in the area of depreciation, for example, to indicate that the choice of depreciation method and the determination of the amount of the annual decline involves consideration of all the following factors:

\footnotetext{
${ }^{20}$ Quoted from CoMmittee on Accounting Procedure, AICPA, Restatement aNd Revision of Accounting Resenrch Bulletins 76 (Accounting Research Bull. No. 43, 1953).
} 
(I) What services are expected of the asset over the years in terms of volume and earnings?

(2) What is the usual trend in cost of repairs and maintenance over the life of the asset?

(3) What evidence is there available as to the decline in efficiency?

(4) What can be expected with respect to the encroachment of obsolescence?

Precise and definite answers to these questions are difficult to determine. But they must be answered and the answers must be translated into practical criteria for selecting the appropriate depreciation method if the accounting profession hopes to achieve a greater degree of comparability in financial reporting. Likewise the profession must develop meaningful criteria for other significant income statement items. How does the accountant determine now, for instance,

which $\left\{\begin{array}{l}\text { pension expense accrual method } \\ \text { investment credit method } \\ \text { depreciation method } \\ \text { income tax expense method } \\ \text { inventory method } \\ \text { etc. }\end{array}\right\} \begin{aligned} & \text { with revenues in a variety of spe- } \\ & \text { cific situations? }\end{aligned}$

The author submits that the accounting profession has never answered these questions and has never instigated any meaningful research that will answer them. Yet the objective of greater comparability between financial statements of entities cannot reach a higher plateau until such questions are answered. ${ }^{\mathbf{3 0}}$

\section{Sumimary and Conclusion}

Many of the problems, misunderstandings, and differences in the concepts of business income and its measurement could be eliminated if the objectives for which income is to be measured were clearly defined and the accounting principles and methodology were then developed to obtain these objectives. It should be more fully recognized that the primary objective of the measurement of business income is to furnish data for decision making. Decision making is concerned with the future, and what has happened in the past is largely irrelevant unless it provides a basis for sound estimates of the future. With the exception of decisions with respect to legal, contractual, and regulatory requirements, such as the determination of taxable income, the amount legally available for dividends, and the amounts payable under bonus and profit-sharing plans, most business decisions are (or should be) based on future expectations about the earning power of a business. This is true for managerial decisions as well as for the decisions made by outsiders such as stockholders, potential investors, creditors, employees, union leaders, and others. There can be no

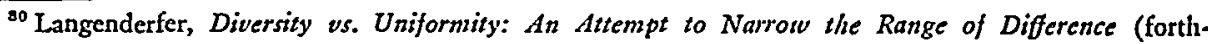
coming). 
certainty about the future earning power of a business, but it is incumbent upon management and the accounting profession to provide a measurement of past business income that gives the most useful basis for estimating future earning power.

It is possible that such a concept and its implementation would require some departure from the "cost" principle and the "realization" principle. Both of these principles have been strongly defended by most accountants on the basis that they provide an objective measurement of business income. It should be recognized, however, that an estimate-even a rough approximation -of useful and pertinent information may be much more valuable to readers of financial statements than a precise determination of objective "facts" that are less useful and pertinent. 